\title{
Sestrinska skrb za bolesnika liječenog VAC terapijom
}

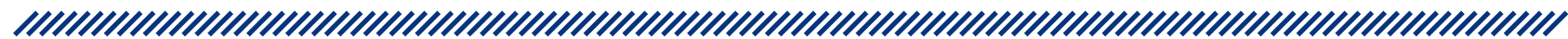

1 Klaudia Knezić

2 Jasmina Kruško

3 Sanela Takus

4 Mateja Krznar

1 Klinički bolnički centar Zagreb, Klinika za kirurgiju, Zavod za plastičnu, rekonstruktivnu i kirurgiju dojke, Zagreb, Hrvatska

2 Klinika za dječje bolesti Zagreb, Referentni centar za pedijatrijsku gastroenterologiju, hepatologiju i poremećaje hrane, Zagreb, Hrvatska

3 Lungenklinik Köln-Merheim, Odjel za pneumologiju/ onkologiju i torakalnu kirurgiju, Njemačka

4 DEBRA, društvo oboljelih od bulozne epidermolize, Zagreb, Hrvatska

\section{Sažetak}

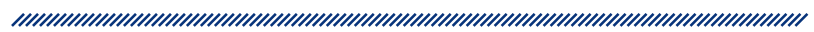

Terapija negativnim tlakom (Vacuum Assisted Closure) je metoda liječenja rana koja se praktično primjenjuje u klinikama diljem svijeta, a počeci joj se naziru još u 1995. godini. VAC sustav osobito je učinkovit u liječenju traumatskih i kroničnih rana.

Uspjeh liječenja VAC terapijom ovisi o nekoliko čimbenika, od kojih su najznačajniji dobra kirurška tehnika, pravilna procjena stanja bolesnika, te planiranje i provođenje postupka s pozitivnom evaluacijom na kraju liječenja. Postupci medicinske sestre kod postavljanja VAC aparata usmjereni su na psihofizičko stanje pacijenta, procjenu kože prije i nakon primjene VAC terapije, procjenu okolnog tkiva, procjenu položaja bolesnika u krevetu, procjenu i prilagodbu mikroklimatskih uvjeta te procjenu prisutnosti rizika od krvarenja. Veoma je važna edukacija bolesnika.

Cilj članka je opisati postupak liječenja kronične rane VAC terapijom te pobliže objasniti zadaće medicinske sestre tijekom VAC terapije. Medicinska sestra mora posjedovati specifična znanja radi provođenja postupka, mora biti educirana u pružanju zdravstvene njege bolesniku s kroničnom ranom te podrška i oslonac bolesniku.

VAC metoda je siguran i uspješan način liječenja, a s obzirom na to da je ekonomski povoljna za zdravstveni sustav i bolesnike, sve je češće metoda izbora u liječenju bolesnika s kroničnim ranama.

Ključne riječi: VAC terapija, kronične rane, zdravstvena njega

Datum primitka: 18.04.2019.

Datum prihvaćanja: 15.01.2020.

https://doi.org/10.24141/1/6/1/14

Adresa za dopisivanje:

Klaudia Knezić

Sutlanske doline 70, Prosinec 10293 Dubravica, Hrvatska

E-mail: klaudia.knezic@gmail.com

T: +385998263354 


\section{Uvod}

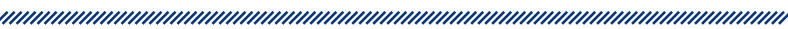

Rana je prekid anatomskog i funkcionalnog kontinuiteta tkiva ili organa. Nastaje djelovanjem mehaničkih, termičkih, kemijskih, bioloških ili električnih čimbenika, te kombinacijom dvaju ili više navedenih čimbenika. Treba razlikovati akutne rane od kroničnih, posebice jer su liječenje i sestrinske intervencije prilikom skrbi za bolesnika s akutnim i kroničnim ranama različiti. Svaka akutna rana može postati kronična ako pravodobno ne prođe svaku fazu cijeljenja rane ${ }^{1}$.

\section{Cijeljenje rane}

Cijeljenje rane definiramo kao proces tijekom kojeg organizam zamjenjuje i obnavlja funkcije oštećenog tkiva različitim procesima. Sastoji se od četiri faze: prva faza je vaskularni odgovor na oštećenje tkiva ili hemostaza, gdje dolazi do vazokonstikcije, a kao posljedica toga i do koagulacije. Druga faza je upalna faza i dijeli se na ranu i kasnu upalnu fazu. Nakon 24-48 sati od nastanka rane formiraju se granulociti te se odstranjuju strana tijela i bakterije iz rane. Tijekom 48-72 sata od nastanka rane dolazi do fagocitoze i limfocitoze, što je ključno za oslobađanje proteolitičkih enzima, koji održavaju ranu čistom. Treća faza je proliferativna faza, tijekom koje se stvara kolageno i granulacijsko tkivo koje zatvara nastalo oštećenje, stvaraju se nove krvne žile, dolazi do kontrakcije rane i epitelizacije. Tijekom četvrte, završne faze, dolazi do sazrijevanja tkiva i remodelacije. Može trajati najmanje 21 dan, a najduže godinu dana od nastanka oštećenja².

Dođe li do zastoja tijekom jedne od navedenih faza cijeljenja rane, ona će prijeći u kroničan oblik i time znatno produljiti tijek liječenja, promijeniti način liječenja te pacijentovo psihofizičko stanje. Kronične rane zahtijevaju intenzivnu skrb za bolesnika, smanjuju kvalitetu života te često vežu bolesnike uza zdravstvene ustanove. Postoje brojni čimbenici, vanjski i unutarnji, koji utječu na liječenje rane. Na neke možemo izravno djelovati, poput negativnog zdravstvenog ponašanja, nesavjesne upotrebe antibiotika i drugih lijekova, neadekvatnih mikroklimatskih uvjeta, osobne higijene i slično. Svrha je smanjivanje broja rizičnih čimbenika te povećanje mogućnosti za brže izlječenje ${ }^{3}$.

\section{Načini liječenja kirurških rana}

Osnovni načini liječenja kirurških rana su primarna obrada rane po Friedrichu, liječenje rana Octeniseptom, liječenje rana oblogama, te debridman ili obrada kirurške rane na nekoliko načina: mehanički, kirurški, autolitički, kemijski ili biološki. Liječenje rane negativnim tlakom spada u novije vrste debridmana, zajedno s vodenim debridmanom ${ }^{4}$.

\section{Postupak liječenja VAC sustavom}

Liječenje rana terapijom negativnog tlaka (NPWT) pomoću vakuumom potpomognutog zatvaranja (VAC-a) pokazalo je dobre rezultate u liječenju kroničnih rana. Radi se o posebnom uređaju koji u rani stvara negativni tlak ispod 125 milimetara žive, a djeluje preko posebnih spužvi koje se umeću u ranu te se prema njoj i oblikuju ${ }^{5}$.

Sekret iz rane se posebnim sustavom odvodi u zatvoreni kontejner unutar aparata. Negativni tlak osigurava optimalnu količinu tekućeg sadržaja u rani i kapilarni protok u cilju poboljšanja kapilarne perfuzije. Na taj se način osiguravaju idealni vlažni uvjeti za cijeljenje rane i odstranjuje odumrlo tkivo i bakterije. Rana i spužve prekrivene su polupropusnom membranom koje su u cijelosti sterilno izolirane, nema mogućnosti onečišćenja rane iz okoline. Na taj način sprječava se sekundarna infekcija rane i širenje bakterija iz rane u okolinu, nema maceracije okolne kože koju uzrokuje sekret iz rane ${ }^{6}$.

Sustav liječenja rana VAC poboljšava perfuziju tkiva za $30 \%$ unutar rane i $15 \%$ u okolnom tkivu, smanjuje edem, znatno smanjuje broj bakterija u rani, čak i MRSA-u. Odstranjuje višak eksudata (zajedno s upalnim citokinima, slobodnim radikalima, tkivnim iritatorima te toksinima) i dovodi do kontrakcije rane. Smanjena je potreba za čestim previjanjem rana, a time i izlaganje riziku od infekcije, jer je rana suha i sterilno prekrivena. Zbog navedenih pozitivnih djelovanja, liječenje VAC terapijom primjenjuje se i kod presađivanja kože te znatno smanjuje mogućnost odbacivanja presatka ${ }^{7}$.

\section{Priprema bolesnika}

Nakon što se specijalist kirurg odluči za liječenje rane negativnim tlakom, u većini slučajeva rana je kronična i velika s većom eksudacijom. 
Ako je rana veća i zahtjevnija, bolesnicima se VAC aparat postavlja u općoj anesteziji, ovisno o veličini rane učini se i kirurški debridma. Potrebno je izvaditi laboratorijske nalaze te zatražiti pisani pristanak bolesnika za opću anesteziju i kirurški zahvat. Ako je rana manja, aparat se može postaviti u previjalištu ili bolesničkoj sobi u lokalnoj anesteziji, pri čemu je iznimno važno poštivati pravila asepse ${ }^{8}$.

O načinu postavljanja VAC aparata odlučuje specijalist na temelju procjene stanja bolesnika i procjene stanja rane. Prije samog zahvata bolesnicima liječnik specijalist objašnjava postupak te bolesnik potpisuje suglasnost. Potrebno je educirati bolesnika o načinu transporta i manipulaciji VAC aparatom. Bolesniku treba dopustiti da postavlja pitanja te mu na njih odgovoriti na njemu razumljivom jeziku i ponuditi literaturu i brošure. Mjesto postavljanja VAC aparata priprema se kao i svaka druga preoperativna površina, prema protokolu. Mjesto na kojem se aparat postavlja mora biti očišćeno po pravilima asepse, a okolina rane čista i suha ${ }^{9}$.

\section{Priprema pribora}

Postavljanje VAC sustava odvija se u uvjetima asepse. Sustav se sastoji od aparata s komandama za unošenje potrebnih podataka te sterilnog seta u kojem se nalazi spremnik za eksudat, silikonski priključak, pjena za ispunjavanje rane te hidrofilm za sigurnosna izolacija rane. Liječnik unosi osnovne parametre u aparat i daje upute medicinskoj sestri što tijekom terapije treba kontrolirati. Medicinska sestra smješta bolesnika u krevet te s njim dogovara koji će položaj bolesnik održavati za vrijeme terapije. Položaj mora biti udoban, ali također mora osigurati nesmetani rad sustava. Jačina i volumen alarma koji signaliziraju nepravilnosti u radu sustava moraju biti prikladno namješteni kako bi se izbjeglo zastrašivanje bolesnika i posjetitelja ${ }^{10}$.

\section{Izvođenje postupka}

Medicinska sestra se predstavlja bolesniku i identificira ga. Još jednom ukratko ponavljaju tijek događaja. Medicinska sestra/tehničar osigurava privatnost i povoljne uvjete u prostoriji, osvjetljenje, mir, čistoću. Prilikom izvođenja postupka medicinska sestra je nesterilni član tima ${ }^{11}$. Pere ruke, smješta bolesnika u pravilan položaj. Ponovno pere ruke i navlači nesterilne rukavice te skida površinski povoj na rani i otvara sterilan set za pranje rane. Liječnik navlači sterilne rukavice i pere ranu. Sestra polijeva smotuljke vate sredstvom za čišćenje rana. Sestra otvara set sa specifičnim priborom. Liječnik obli- kuje spužvu od poliuretanske pjene prema veličini rane, postavlja spužvu na ranu te preko nje stavlja zaštitnu foliju. Folija se reže sterilnim škarama na mjestu koje odgovara sredini rane. Na urezani dio folije postavlja se odvodna cijev, tzv. port, koji se spaja na VAC aparat. Port služi za odvođenje sekreta u kontejner. Liječnik upisuje željene podatke u uređaj te daje sestri detaljne upute o kontroli rada uređaja. Medicinska sestra odlaže upotrijebljeni materijal na za to predviđena mjesta. Tijekom cijelog postupka u središtu pozornosti je bolesnik, kojemu se objašnjava svaki postupak koji slijedi. Medicinska sestra odvodi bolesnika u njegovu sobu te ga smješta u udoban položaj. Uočava promjene na bolesniku (nemir, nesigurnost, bol), kontrolira rad VAC uređaja, mjesto priključka, okolnu kožu i spremnik za eksudat. Obavještava liječnika u slučaju pojave neželjenih reakcija. Dezinficira i suši ruke nakon izlaska iz bolesničke sobe. Dokumentira postupak, vrijeme postavljanja VAC sustava i eventualne reakcije ${ }^{12}$.

\section{Zadaće medicinske sestre pri skrbi o bolesniku na VAC terapiji}

Medicinska sestra prati vitalne znakove bolesnika nakon postavljanja VAC sustava. Prati i evidentira količinu i specifičnosti eksudata, ranu i prevoje te okolnu kožu. Kod bolesnika se javlja smanjena mogućnost brige za sebe u smislu obavljanja osobne higijene, presvlačenja i obavljanja fizioloških potreba, posebice prvih nekoliko dana dok se bolesnik ne navikne na novi način liječenja. U tim trenucima je vrlo važno razviti dobre odnose i povjerenje. Vrlo je bitno pratiti pojavu i intenzitet boli te primijeniti analgeziju prema uputama liječnika.

Medicinska sestra je bolesniku oslonac i podrška. Razgovara s bolesnikom te upućuje njega i njegovu obitelj. O bitnim promjenama obavještava liječnika ${ }^{13}$.

\section{Edukacija}

Potrebno je educirati bolesnika o prepoznavanju i sprečavanju mogućih komplikacija na temelju znakova i simptoma komplikacija - bol, pritisak, crvenilo, krvarenje, hematom, toplina okolne kože. Ako bolesnik nema snage, volje ili želje za obavljanjem svakodnevnih radnji poput obavljanja osobne higijene, treba mu pomoći, radeći to na takav način koji će mu pomoći da se što prije osamostali. Bolesnika treba educirati o samom radu $\mathrm{i}$ praćenju VAC aparata ako specijalist odluči nastaviti liječenje rane u izvanbolničkim uvjetima. Bolesnik dobiva usmene upute, pisane brošure te prolazi praktični 
dio edukacije o VAC aparatu koju provodi medicinski tim koji je o bolesniku skrbio za vrijeme hospitalizacije. U takvom je slučaju ključna timska suradnja medicinske sestre $s$ liječnikom ${ }^{13}$. Stečeno znanje bolesnika evaluira se usmenim putem, bolesnik nabraja komplikacije, opaža zvuk i rad samog VAC aparata. Postoji mogućnost da se začepi odvodna cijev, rana može prokrvariti, folija se može odlijepiti s operativnog polja. VAC aparat alarmira ako dođe do naglog gubitka negativnog tlaka. Bolesniku se objasni kako zvuči aparat kada normalno radi, a kako zvuči kada počinje gubiti negativni tlak. Gubitak negativnog tlaka dovodi do zvučnog signala samog VAC aparata. VAC počinje alarmirati. Bolesnicima liječnik objasni kako i zašto VAC alarmira. Ako bolesnik primijeti odstupanje od normalnoga, poziva medicinsku sestru/tehničara koji postupaju prema protokolu.

\section{Promatranje bolesnika i rane}

Medicinska sestra aktivno sudjeluje u postupku postavljanja VAC aparata, promatra mjesto postavljanja aparata od postavljanja do skidanja, stalno je prisutna i jedina ima 24-satni uvid u stanje rane. Procjenjuje bol kod bolesnika na skali za procjenu boli od 1 do 10 . Kontrolira stanje krvarenja ako postoji (količinu, boju, protok sekrecije koji cirkulira unutar VAC aparata). Prati okolno tkivo, boju, toplinu. Dokumentira svaku promjenu spužve i obloge, dokumentira stanje i izgled rane. Kontrolira rad aparata prema uputama liječnika, dokumentira i mijenja VAC kontejner (tablica 1.). U slučaju komplikacija obavještava liječnika ${ }^{14}$.

\section{Zaključak}

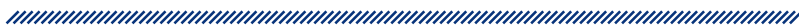

Dokazano je da se radi o kvalitetnoj metodi liječenja s izvanrednim rezultatima i evidentno povoljnim odnosom cijene i koristi. Terapija je sigurna te je kao takva primjenjiva u bolničkim, ambulantnim te kućnim uvjetima. Bitno je stvoriti odnos povjerenja s bolesnikom i njegovom obitelji jer je dobra suradnja ključna u edukaciji. Sestra kao edukator ima osobito odgovornu ulogu jer ona mora bolesniku na razumljiv način objasniti njegovo trenutno stanje te način na koji će se ponašati u novonastaloj situaciji.

Tablica 1. Praćenje VAC aparata

Ime i prezime:

Dijagnoza:

Operater:

Operativni dan:

\begin{tabular}{|l|l|l|c|c|}
\hline DATUM & POST. OP. & VRIJEME & $\begin{array}{c}\text { PROMJENA VAC KONTENJERA } \\
\text { IZGLED MJESTA INSERCIJE }\end{array}$ & $\begin{array}{c}\text { POTPIS MED. } \\
\text { SESTRE }\end{array}$ \\
\hline & & & \\
\hline & & & \\
\hline
\end{tabular}




\section{Reference}

8. Huljev D, Gajić A, Gverić T, Kecelj Leskovec N, Triller C. Uloga terapije negativnim tlakom u tretmanu kroničnih rana. Acta Med Croatica. 2012; 66(1):59-64

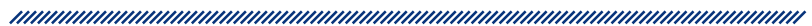

1. Hančević J, i sur. Rana. Naklada Slap. Jastrebarsko. 2000.

2. Brem H, Sheehan P, Rosenberg HJ, Schneider JS, Boulton AJ. Evidence-based protocol for diabetic foot ulcers. Plast Reconstr Surg. 2006;117:193-209

3. Mendez-Eastman S. When wounds wounds won't heal. RN. 1998;61(1):20-3

4. Huljev, D. V.A.C.- terapija inovacija u liječenju kronične rane. Vaše zdravlje. 2006;50(10/6)

5. Maruccia M, Onesti MG, Sorvillo V, Albano A, Dessy LA, Carlesimo B, i sur. An Alternative Treatment Strategy for Complicated Chronic Wounds: Negative Pressure Therapy over Mesh Skin Graft. Biomed Res Int. 2017; 2017: 8395219

6. Armenio A, Cutrignelli DA, Nardulli ML, Maggio G, Memeo G, De Santis V, i sur. Bio-Engineering tissue and V.A.C. therapy: A new method for the treatment of extensive necrotizing infection in the diabetic foot. Ann Ital Chir. 2017;88:268-274

7. Rauche. Vakum terapija u tretmanu hronične rane. Dostupno na: http://www.rauche.net/izdanja/broj-4/vakum-terapija-u-tretmanu-hronicne-rane/ Datum pristupa stranici 11.04.2019

9. Gabriel A, Rauen B. Simplified negative pressure wound therapy with instillation: advances and recommendations. Plast Surg Nurs. 2014;34(2):88-92

10. Ellis G. How to apply vacuum-assisted closure therapy. Nurse Stand. 2016;2;30(27):36-9

11. Kalauz S. Upravljanje kvalitetom u zdravstvenoj njezi. Zagreb. Zdravstveno Veleučilište. 2008.

12. Palm HG, Hauer T, Simon C, Willy C. Vacuum-assisted closure of head and neck wounds. HNO. 2011;59(8):819-30

13. Priručnik o standardima kvalitete zdravstvene zaštite $i$ načinu njihove primjene. Agencija za kvalitetu i akreditaciju u zdravstvu. Zagreb. 2011. Dostupno na: http:// www.aaz.hr/sites/default/files/prirucnik o standardima kvalitete zdravstvene zastite i nacinu njihove primjene 0.pdf Datum pristupa stranici: 11.04.2019

14. Ali Z, Anjum A, Khurshid L, Ahad H, Maajid S, Dhar SA. Evaluation of low-cost custom made VAC therapy compared with conventional wound dressings in the treatment of non-healing lower limb ulcers in lower socioeconomic group patients of Kashmir valley. J Orthop Surg Res. 2015;10:183 


\section{NURSING CARE FOR PATIENTS USING VAC THERAPY}

\section{Summary}

Negative Pressure Therapy - Vacuum Assisted Closure - is a wound treatment method used in clinical practice throughout the world. Its beginnings date back to the year 1995. The VAC system is particularly effective in treatment of traumatic and chronic wounds.

The success of VAC therapy treatment depends on several factors, the most important of which are a good surgical technique, proper assessment of the patient's condition, and planning and conducting procedure, which are positively evaluated at the end of the treatment. Nurse's interventions are focused on assessment of the patient's psychophysical condition, skin condition assessment before and after the treatment, assessment of the skin surrounding the wound, proper body position during the procedure, assessment and adjustment of microclimate conditions, as well as bleeding risk estimate. Education of the patient must be accentuated as the most important intervention.

The objective of this article is to describe the procedure of chronic wound treatment using VAC system and to explain the tasks of nurses in the course of VAC therapy. Nurses need to possess specific knowledge for the purpose of conducting the procedure, they need to be educated in providing the patient's health care, and they need to provide support both to the patient and their family.

VAC method is a safe and successful treatment method and since it is economically affordable both for the healthcare system and the patients, it is increasingly frequently selected for the treatment of patients with chronic wounds. 